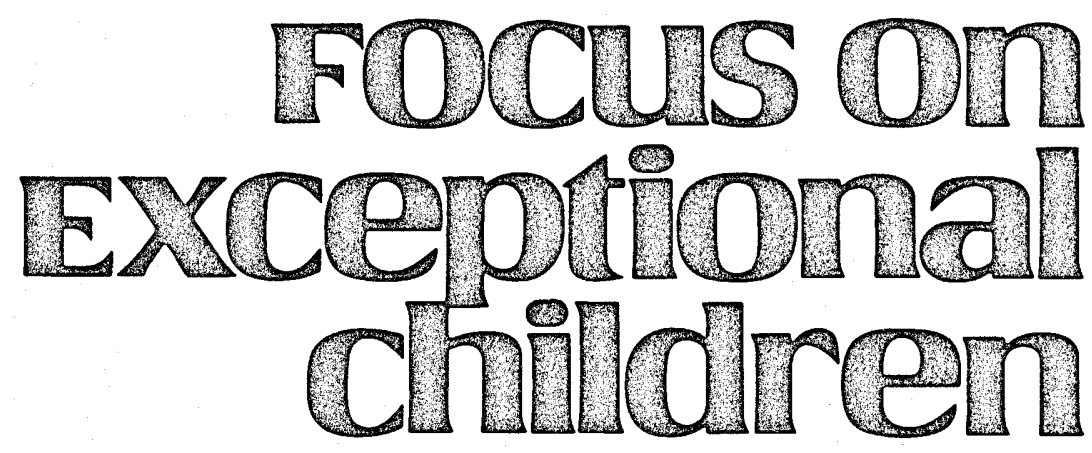

\title{
Effective Mathematics Instruction: Development, Instruction, and Programs
}

John Wills Lloyd and Clayton E. Keller

We see effective instruction as having three important characteristics:

1. It is based on empirical evidence about development and use of the knowledge and skills that comprise the area to be taught.

2. It is delivered using instructional procedures that have been shown to have positive effects on pupil outcome.

3. It uses programs that have been empirically validated.

At a minimum, providing content instruction requires some way of delivering that content. But, to the extent that we can incorporate knowledge about the ways people act and think when correctly and efficiently handling that content (point 1 ), we can make instruction more effective. Of course, other things being equal, we assume that people (teachers, parents, administrators, students, and others) would prefer to have students taught by teachers who use effective instructional techniques to deliver the content (point 2). Similarly, we assume that people would prefer to have students taught using the most effective instructional programs available (point 3); that is, we presume that people would favor instructional materials that have a demonstrated record of success.

Along these lines, our purpose in this article is to illuminate what is known about providing effective instruction in mathematics. We begin with some illustrations about the growing understanding of children's thinking in mathematics, follow that with a discussion of the application of effective teaching procedures, and conclude with an examination of research about effective procedures and programs.

John Lloyd is affiliated with the Department of Curriculum, Instruction, and Special Education, University of Virginia. Clayton Keller is affiliated with Education and Human Service Professions, University of Minnesota at Duluth. 


\section{COGNITIVE DEVELOPMENT IN MATHEMATICS}

Much of the current research in mathematics education and cognitive psychology focuses on what pupils know and do when solving mathematical problems. In this section we illustrate this research by describing how students develop basic knowledge about numbers and strategies for manipulating them. Because one of the most thoroughly studied areas concerns the algorithms that preschool and primary-grade students use when solving simple addition problems, we highlight this area but also make references to more sophisticated types of performance. Researchers have considered (a) differences in the strategies learners use, and (b) knowledge about numbers and arithmetic procedures needed to use the strategies (Pellegrino \& Goldman, 1987).

\section{Strategies}

To some extent, nonhandicapped learners apparently develop their own algorithms for solving problems involving

\section{Focus on
Exceptional children}

FOCUS ON EXCEPTIONAL CHILDREN (ISSN0015-511X) (USPS 203-360) is published monthly except June, July, and August as a service to teachers, special educators, curriculum specialists, administrators, and those concerned with the special education of exceptional children. This publication is annotated and indexed by the ERIC Clearinghouse on Handicapped and Gifted Children for publication in the monthly Current Index to Journals in Education (CIJE) and the quarterly index, Exceptional Children Education Resources (ECER). It is also available in microform from Xerox University Microfilms, Ann Arbor, MI. Subscription rates: Individuals, $\$ 24$ per year; institutions, $\$ 30$ per year. Copyright (C) 1989 , Love Publishing Company. All rights reserved. Reproduction in whole or part without written permission is prohibited. Printed in the United States of America. Second class postage is paid at Denver, Colorado.

POSTMASTER: Send address changes to:

Love Publishing Company

Executive and Editorial Office

1777 South Bellaire Street

Denver, Colorado 80222

Telephone (303) 757-2579

\section{EDITORIAL BOARD}

\begin{tabular}{cc} 
Edward L. Meyen & Glenn A. Vergason \\
University of Kansas & Georgia State University \\
Richard J. Whelan & \\
University of Kansas Medical Center \\
Stanley F. Love & Carolyn Acheson \\
Publisher & Senior Editor \\
\hline
\end{tabular}

numbers (Romberg \& Carpenter, 1986), whether they are left to their own devices (e.g., Groen \& Resnick, 1977) or are provided specific instruction in the use of certain algorithms (e.g., Houlihan \& Ginsburg, 1981; Russell, 1977). Carpenter and Moser (1983) described three levels of development in addition strategies.

In the first level, called counting all with models, children use strategies in which physical objects (including fingers) represent the addends of the problem. Objects are set out for each addend, the sets of objects are combined either physically or conceptually, and then they are counted (starting at one).

At the second level, called counting sequences without models, learners do not depend on objects. In the first strategy at this level, called Sum (Groen \& Parkman, 1972), the children use the counting-all-with-models strategy but do not use physical models of the addends. The second strategy at this level is called counting on from first. The pupil begins counting by naming the first addend and then counts on from the starting place the number of counts indicated by the second addend. For example, to solve the problem $3+5$, the child would say " 3 ," then count " $4,5,6,7,8$." The third strategy at this level is counting on from larger or Min (Groen \& Parkman, 1972). Although this strategy is similar to the previous one, it is slightly more efficient. The child first determines which addend is larger (" 3 plus $5 \ldots 5$ is larger"), names that addend ("5 . ."), and counts on for the other, smaller addend (" $6,7,8$ "). It is called Min because it requires the minimum number of counting steps.

Strategies at the third level use number facts that the learner knows (Carpenter \& Moser, 1983). Children can recall some facts-doubles or ties (e.g., $4+4)$-rapidly, even at a relatively early age (Groen \& Parkman, 1972). In the strategies at this level, they use these known facts to solve other problems; for example, the child might think, " 5 plus $6 \ldots 5$ and 5 is 10 , and 6 is one more than 5 , so my answer has to be one more . . 11." Eventually, most children will solve simple problems just by using known facts. Use of this strategy becomes predominant around the third grade for children with normally developing arithmetic skills (Ashcraft, 1982).

Development of these strategies permits some generalizations to be made about the acquisition of mathematical skills (Carpenter \& Moser, 1983). First, each succeeding strategy builds on strategies learned previously. Second, as learners progress through the levels of strategies, they become more flexible in using strategies to solve various kinds of addition 
problems. Last, the strategies increase in abstraction and efficiency; for example, in later strategies pupils simply let a numeral stand for a number of objects, whereas in an earlier strategy they put out a number of objects for each numeral.

Although learners gradually adopt more efficient strategies, they do not always use the most efficient strategies available to them (Carpenter \& Moser, 1983). In fact, they use different strategies, often depending upon the particular addition problems they encounter (Houlihan \& Ginsburg, 1981; Russell, 1977; Siegler \& Robinson, 1982). In a longitudinal study of pupils in first through third grades, Carpenter and Moser (1984) found great variability in the use of strategies both within a testing session and from one session to another. For example, some children who were capable of efficient counting strategies such as Min would use less efficient strategies if manipulatives were available. But no clear patterns of strategy use emerged relative to type of word problem or size of the numbers involved.

Also, research suggests that students with difficulties in mathematics, such as some learning disabled students, may use the same strategies that competent math students use but may use them in ways that contribute to problems with the tasks. Geary, Widaman, Little, and Cormier (1987) found that students with disabilities in math (including learning disabled students in the sixth grade) seemed to use counting strategies instead of memory-retrieval strategies to solve basic addition facts, took longer to execute these counting strategies, and had difficulties monitoring the execution of the strategies. Svenson and Broquist (1975) suggested that poor achievers' slow reaction times for solving basic addition fact problems might be the result of difficulty in determining which addend was larger and where to start the counting process when using the Min strategy.

\section{Conceptual Knowledge}

Along with examining the procedures of addition strategies, researchers (e.g., Resnick, 1983; Fuson, 1982; Secada, Fuson, \& Hall, 1983) also have studied learners' understanding of numbers and addition. When using Min (or any other mathematics strategy), learners manipulate the parts of arithmetic problems and numbers. According to Resnick, these strategies "provide evidence that children understand the structure of numbers and are able to partition and recombine with some flexibility" (pp. 121-122). Such understanding and ability are possible because children organize their knowledge about numbers into a representation or schema. The child, however, does not have to be able to describe his or her representation.
Schema can develop from everyday experiences such as counting things and noticing the relationships between parts and wholes. Numbers do not have to be involved in the origin of the representation. Simple forms of the representation that do involve actual numbers, however, could be related to simple procedures (e.g., counting up from a given number) for solving problems. Experiences with numbers then lead to further development of the representation and of new procedures.

In sum, two major points that have implications for instruction appear in the research about cognitive processes.

- As children become more proficient in addition, they develop strategies that are (a) based on previous strategies, (b) more efficient than earlier ones, and (c) likely to be similar to patterns of development in other individuals. Ideally, in choosing strategies to teach, one probably should choose strategies that are the most efficient. But can the most efficient strategies be taught without previous exposure to the preceding sequence of less efficient strategies?

Often, we teach pupils something akin to the counting-all-with-models strategy and then go directly to teaching them to memorize each combination as a fact. Might this be the source of some of the problems that pupils experience in mathematics? Can atypical learners skip the intermediary steps as readily as their peers?

- Conceptual and procedural knowledge are linked and change together. Thus, although the stress is usually on teaching pupils how to perform arithmetic operations, instructional approaches maybe should teach concepts while attempting to change procedural strategies.

\section{EFFECTIVE PRESENTATION}

Many features of how teachers present material influence the learning of pupils being taught. These include providing adequate opportunities to learn, emphasizing academic learning, communicating expectations that the pupils can learn, actively leading instruction, and so forth (Brophy \& Good, 1986). This model is generally referred to as the direct instruction approach (Rosenshine, 1976). ${ }^{1}$ In addi-

\footnotetext{
${ }^{T}$ Following the form of others (e.g., Becker \& Carnine, 1981), we must discriminate between the version of direct instruction described by Rosenshine (e.g., 1976) and the model proposed by Engelmann, Becker, and Carnine (e.g., Becker, 1986; Engelmann \& Carnine, 1982)-labeled the "Direct Instruction Model" during the late 1960s and early 1970s as a part of the Follow Through Project. Current, everyday use of the term "direct instruction" in educational circles probably is more similar to Rosenshine's than to Engelmann, Becker, and Carnine's. Our use here is tied to citations of the source.
} 
tion, some more molecular aspects of teaching presentations (e.g., reinforcement) increase pupil performance. In this section we first discuss the overall model of effective teaching as it applies to mathematics instruction and then describe some of the more detailed techniques.

\section{Direct Instruction}

Although educators may differ about the relative emphasis on parts of the model, they generally agree that teachers who are teaching orderly subjects such as mathematics are more likely to be effective if they:

- Begin a lesson with a short review of previous, prerequisite learning.

- Begin a lesson with a short statement of goals.

- Present new material in small steps, with student practice after each step.

- Give clear, detailed instructions and explanations.

- Provide a high level of active practice for all students.

- Ask a large number of questions, check for student understanding, and obtain responses from all students.

- Guide students during initial practice.

- Provide systematic feedback and corrections.

- Provide explicit instruction and practice for seatwork exercises and, when necessary, monitor students during seatwork. (Rosenshine \& Stevens, 1986, p. 377)

Application of these broad guidelines to mathematics instruction is clearly illustrated in a part of the Missouri Mathematics Effectiveness Project (e.g., Good \& Grouws, 1979; for an extensive set of recommendations, see Good, Grouws, \& Ebmeier, 1983). In this project teachers implemented their mathematics instruction for 4 months according to the guidelines for teaching given in Table 1 . The results showed that the percentile scores of students in the experimental classrooms increased over 30 points.

A particularly important aspect of the findings from this project was that the treatment program had especially beneficial effects on lower-performing students (Ebmeier \& Good, 1979). Major reviews emphasize the importance of these teaching behaviors for low-performing students. Brophy and Good say that "low-achieving students need more control and structuring from their teachers: more active instruction and feedback" (1986, p. 365). Rosenshine and Stevens (1986) make similar observations. Additional support for the importance of this approach with atypical learners is available in the literature on specific parts of teachers' instructional behavior.

\section{TABLE 1 \\ Recommendations for Effective Instruction From the \\ Missouri Mathematics Effectiveness Project}

Daily Review (first 8 minutes except Mondays)

(a) review the concepts and skills associated with the homework

(b) collect and deal with homework assignments

(c) ask several mental computation exercises

Development (about 20 minutes)

(a) briefly focus on prerequisite skills and concepts

(b) focus on meaning and promoting student understanding by using lively explanations, demonstrations, process explanations, illustrations, etc.

(c) assess student comprehension

(1) using process/product questions (active interaction)

(2) using controlled practice

(d) repeat and elaborate on the meaning portion as necessary

Seatwork (about 15 minutes)

(a) provide uninterrupted successful practice

(b) momentum - keep the ball rolling-get everyone involved, then sustain involvement

(c) alerting-let students know their work will be checked at end of period

(d) accountability - check the students' work

Homework Assignment

(a) assign on a regular basis at the end of each math class except Fridays

(b) should involve about 15 minutes of work to be done at home

(c) should include one or two review problems Special Reviews

(a) weekly review/maintenance

(1) conduct during the first 20 minutes each Monday

(2) focus on skills and concepts covered during the previous week

(b) monthly review/maintenance

(1) conduct every fourth Monday

(2) focus on skills and concepts covered since the last monthly review

From "The Missouri Mathematics Effectiveness Project: An Experimental Study in Fourth-Grade Classrooms" by T.L. Good and D.A. Grouws, 1979, Journal of Educational Psychology, 71. Reprinted by permission. 


\section{Specific Teaching Behaviors}

Among the many other things that teachers should do, they must present a fact, concept, or procedure in some way. This usually is done by modeling the fact, concept, or procedure. Then, when pupils practice using the fact, concept, or procedure, the teacher must provide consequences that are related to their performance-particularly reinforcement and corrections. The effects of modeling and reinforcement have been studied extensively.

\section{Modeling}

Modeling or demonstrating is a time-honored teaching mechanism. Models occur in any of many different forms. The teacher may use modeling by:

- Stating a fact or rule (e.g., "Any number times zero equals zero").

- Performing a task (e.g., "Watch me. I'm going to do this long division problem. First, uhmm, I estimate how many times this [pointing to the divisor] will go into this [pointing to the dividend]. Let me see, 19 is almost 20 and 20 will go into 50 about 2 times. . .).

- Having students observe a shill (another student or teacher) answer a question (e.g., "Let's see if Jane knows this one-Jane, what's another way to say $10^{3}$ ?") or perform a task (e.g., "Watch Jeff; he's going to show us how to multiply a binomial").

Simply modeling appropriate performance can have surprising effects on student behavior in mathematics. For instance, Smith and Lovitt (1975; see also Rivera \& Smith, 1988) found that supplying learning-disabled boys with a demonstration and a permanent model (a problem and its solution written on the boys' worksheets) markedly improved the boys' performance. Not only did the boys' performance on the target problems improve, but it also improved on other problems for which they had not received models.

\section{Reinforcement}

As in most other learning, operant reinforcement plays an important role in acquisition of arithmetic skills and knowledge. In the early stages of learning, correct responses that are reinforced are more likely to recur. In later stages of learning, reinforcement also may be useful. For example, if students answer too slowly (not automatically) or inconsistently, reinforcement of higher rates of responding or more accurate responding can improve their performance (e.g., Hasazi \& Hasazi, 1972; Smith, Lovitt, \& Kidder, 1972).

Reinforcement is of lesser value when students do not know how to perform a task. Studies with handicapped learners have shown that the effectiveness of reinforcement contingencies depends upon students' being capable of performing the target response (Grimm, Bijou, \& Parsons, 1973; Smith \& Lovitt, 1976).

In addition to the forms of reinforcement with which we are all familiar (praise, token rewards, and so on), reinforcement can take subtle forms. For instance, Fink and Carnine (1975) found that having students maintain graphs of their progress reinforced their levels of performance in arithmetic. Furthermore, simply acknowledging that an answer is correct probably serves as reinforcement. Thus, teachers who nod, say "yes," or repeat students' correct answers are appropriately providing reinforcement.

\section{Corrections}

When students answer questions or perform algorithms incorrectly, they provide perhaps one of the most important opportunities to teach. Corrections are the teaching actions that teachers take under such circumstances. Corrections should neither be viewed as punishment nor delivered in a punishing fashion. When the incorrectly answered question is simple or factual (e.g., the teacher points to a numeral and says, "What number is this?"), the most appropriate correction is to model the correct answer for the student. When the mistaken response is made after the student has completed an algorithm or strategy, probably the most appropriate correction is to model the correct use of the algorithm.

Mistakes that students make on algorithmic problems are often systematic, revealing a mistaken strategy (Brown \& Burton, 1978; Cox, 1975; Ginsburg, 1977; Lankford, 1972; Young \& O'Shea, 1981). By analyzing these errors, teachers can ascertain on which specific part of a solution algorithm they should focus correction procedures.

Some additional procedures that have been studied in the area of mathematics may be useful when students make errors. For example, two studies have used interventions that cue pupils' access to appropriate procedural knowledge for computation problems. Lovitt and Curtiss (1968) required a student to read each problem aloud before writing the answer to it. This procedure produced beneficial effects on the student's arithmetic performance. Similarly, Parsons (1972) required pupils to both circle and name the operation symbols (a plus or a minus) of a problem prior to performing 
the arithmetic operation. This technique increased accuracy among students who had often performed the wrong operation.

In short, effective mathematics instruction must incorporate aspects of teaching behavior that have been shown to be related to achievement. We have solid information about the general form of these behaviors, such as was described in the Missouri Mathematics Effectiveness Project. And we know that the use of specific procedures such as reinforcement have very clear, immediate effects on performance. Effective programs should incorporate these.

\section{PROGRAMS}

Information about how pupils think has implications for the content and organization of effective instruction. This information and the information about effective teaching procedures, when combined with what is known from field studies of teaching mathematics, outlines effective teaching. Two major groups of field studies of mathematics are pointed out in this section. In one, researchers have focused on teaching some fairly specific aspect of mathematics content or skill. In the other, comprehensive mathematics programs have been studied.

\section{Target Skills and Knowledge}

Studies focusing on specific skills illustrate how interventions can address access to appropriate content knowledge or increase content knowledge. The content knowledge may be declarative (for example, knowing facts about numbers and their relations), or it may be procedural (knowing how to perform solution algorithms). These studies are summarized in Table 2.

One challenge that teachers face is teaching declarative content to students. Haupt, Van Kirk, and Terraciano (1975) described a simple method for increasing declarative knowledge and automatic recall of number facts. Gradually they obscured the answers to simple subtraction problems by covering each answer with cellophane. This condition was contrasted with a control condition in which the student received traditional drill-and-practice instruction in addition. Haupt et al. found that the fading procedure (combined with reinforcement) resulted in the child reaching criterion nearly twice as rapidly and making five times fewer errors than the control condition. Similarly strong results were observed at follow-up testing.

Sometimes, as the developmental literature on addition indicates, knowledge of basic facts is best taught as procedural knowledge at first and only later brought to the automatic level. Several studies have examined how to teach pupils procedural knowledge. In one model of how to teach procedural knowledge-academic strategy trainingteachers model the steps of an algorithm that students use to solve a specific type of problem (Cullinan, Lloyd, \& Epstein, 1981; Lloyd, 1980; Lloyd \& de Bettencourt, 1982). According to this approach, a task analysis of the skills needed to solve a class of problems is completed. Then students are tested to ascertain which, if any, of the requisite skills they have learned. Finally, they are taught the unknown skills and how to link them together to solve the problems. An example of the use of a strategy of this sort is shown in Table 3. Research has revealed that:

- Atypical students can learn algorithms for simple tasks such as number-numeral equivalences (Grimm et al., 1973) and more complex tasks such as long division (Rivera \& Smith, 1988).

- Pre-teaching of the component skills of a strategy prior to learning how to use the skills in concert leads to greater generalization (Carnine, 1980).

- Failure to pre-teach component skills prior to teaching the students how to use the strategy inhibits generalization (Lloyd, Saltzman, \& Kauffman, 1981).

- Students can learn closely related strategies for closely related tasks (e.g., multiplication and division) without confusing the strategies (Lloyd et al., 1981).

- During acquisition of strategies, teachers should prompt the use of each step in the algorithm, but as the pupils approach mastery of the algorithm, teachers should decrease the level of prompting until the students are functioning independently (Paine, Carnine, White, \& Walters, 1982).

Various authors have used other variations on strategy training. For example, Montague and Bos (1986) studied adolescents working on two-step word problems. The strategy training program incorporated many components"paraphrasing, visualization, detecting relevant information, locating the question, hypothesizing, estimating, labeling, and checking" (p. 26) -and was expected not only to improve pupils' performance but also to affect the way they thought about approaching problems.

In a study of the arithmetic performance of pupils with behavior disorders, Davis and Hajicek (1985) also called one of their treatment conditions "strategy training." In this program, the teacher demonstrated an algorithm for solving multiplication problems involving decimals. Then the teacher had the students imitate the strategy. In a later con- 


\section{TABLE 2}

\section{Studies Focusing on Content Knowledge}

\begin{tabular}{|c|c|}
\hline Study & Math Content \\
\hline Albion \& Salzberg (1982) & addition \\
\hline Cameron \& Robinson (1980) & addition and subtraction \\
\hline Davis \& Hajicek (1985) & decimal multiplication \\
\hline $\begin{array}{l}\text { Haupt, Van Kirk, \& Terraciano } \\
(1975 \text {, Exp. 1) }\end{array}$ & subtraction (basic facts) \\
\hline $\begin{array}{l}\text { Haupt, Van Kirk, \& Terraciano } \\
\text { (1975, Exp. 2) }\end{array}$ & $\begin{array}{l}\text { multiplication } \\
\text { (basic facts) }\end{array}$ \\
\hline $\begin{array}{l}\text { Johnston, Whitman, \& Johnson } \\
\text { (1981), Johnston \& Whitman (1987), } \\
\text { Whitman \& Johnston (1983) }\end{array}$ & addition and subtraction \\
\hline $\begin{array}{l}\text { Lloyd, Saltzman, \& Kauffman } \\
\text { (1981) }\end{array}$ & $\begin{array}{l}\text { multiplication and } \\
\text { division (basic facts) }\end{array}$ \\
\hline Lovitt \& Curtiss (1968) & computation problems \\
\hline Montague \& Bos (1986) & two-step word problems \\
\hline Parsons (1972) & addition and subtraction \\
\hline Schunk(1981) & division \\
\hline Schunk \& Cox (1986) & subtraction \\
\hline $\begin{array}{l}\text { Thackwray, Meyers, Schleser, \& } \\
\text { Cohen (1985) }\end{array}$ & addition \\
\hline
\end{tabular}

\section{Study}

Albion \& Salzberg (1982)

Cameron \& Robinson (1980)

Davis \& Hajicek (1985)

Haupt, Van Kirk, \& Terraciano (1975, Exp. 1)

Haupt, Van Kirk, \& Terraciano (1975, Exp. 2)

Johnston, Whitman, \& Johnson (1981), Johnston \& Whitman (1987), Whitman \& Johnston (1983)

Lloyd, Saltzman, \& Kauffman

Lovitt \& Curtiss (1968)

Cohen (1985)

\section{Intervention and Cognitive Purpose}

general and task-specific self-instructional training (metacognition to guide procedural knowledge)

task-specific self-instructional training (metacognition to guide procedural knowledge)

teacher model, attention to task, self-reinforcement (train procedural knowledge, metacognitive strategies)

cover answers with cellophane (increase declarative knowledge, automaticity)

cover answers with tracing paper (increase declarative knowledge)

self-instructional training (metacognition to guide procedural knowledge)

teach solution algorithm (train procedural knowledge)

read problems aloud before answering (cue access to procedural knowledge)

paraphrase, visualize, detect information, locate question, hypothesize, estimate label, check (train procedural knowledge metacognitive strategies)

circle and name operation sign (cue access to procedural knowledge)

teacher model, corrective feedback (metacognition to guide procedural knowledge)

students verbalize aloud, attribution training (metacognition to guide procedural knowledge)

general and task-specific self-instructional training (metacognition to guide procedural knowledge) dition the teacher repeated modeling of the strategy and added to it a combination of steps to promote pupils' attention to task and self-reinforcement.

Schunk (1981) investigated the effects of demonstrating to low-achieving pupils an algorithm for solving division problems. Students observed a trainer solving division problems and verbalizing the steps in the strategy. Later they practiced the strategy and received corrective feedback that included modeling of the steps. In a related study, Schunk and Cox (1986) found that when learning disabled children were required to verbalize as they solved problems, they obtained higher scores on similar tasks.
Johnston and Whitman evaluated the effects of self-instructional programs with mentally retarded children (Johnston, Whitman, \& Johnson, 1981; Whitman \& Johnston, 1983) and with children who had low levels of prior knowledge about arithmetic operations (Johnston \& Whitman, 1987). Self-instruction, which usually includes self-verbalization of a procedural algorithm for approaching certain kinds of problems, often includes components of self-monitoring and self-reward as well. The programs that Johnston and Whitman used included instruction in the use of strategies for solving specific types of arithmetic problems. In all three studies the results indicated that this inter- 
TABLE 3

Example of a Solution Algorithm for Finding Equivalent Fractions

\section{Step}

1: Read

2: Plan

3: Rewrite

4: Identify

known part

5: Solve

known part

6: Substitute

7: Derive missing numerator

8: Read

\section{Description}

Pupil reads problem to himor herself.

Pupil describes general process to him- or herself.

Pupil rewrites problem, providing space for work. Note: This step can be completed while performing step 2.

Pupil identifies part of equivalence for which numbers are known.

Pupil uses prior knowledge to solve for missing multiplier.

Pupil uses information derived in Step 5 to complete fraction in equation.

Pupil solves for missing numerator using information from Step 6.

Pupil reads completed problem.

\section{Action}

"Let's see ... um, $9 / 17$ ths is equal to how many 102nds?"

"Okay, I've got to multiply 9/

17 ths by some fraction that's the same as 1 , and then I can get the number of 102 nds that it equals."

"Here's my workspace. . .."

$$
\frac{9}{17}(-)=\frac{?}{102}
$$

"Okay. I've got two out of three numbers here (pointing to denominators), so I can start on that part."

"So, 17 times something equals 102 . . . um . . . l'll just figure that out . . . 17 is almost 20 and 20 goes into 100 five times, so l'll try that . . nope, 17 leftover, so it's 6 times... great! It's even."

$$
\frac{9}{17}(-)=\frac{?}{102}
$$

"And that means this (writing) is 6 over 6 ... which is the same as 1 , so..."

$$
\begin{gathered}
\frac{9}{17}(-)=\frac{?}{102} \\
\frac{17 \sqrt{\frac{102}{95}}}{\frac{95}{17}}
\end{gathered}
$$
"Now, I can just multiply these 'cause l've got two out of three and . . .6 times 9 is 54 , sooo..."

"9/17th is equal to $54 / 102 n d s . "$

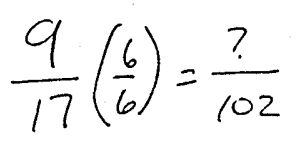

$\frac{9}{17}\left(\frac{6}{6}\right)=\frac{?}{102}$

$\frac{9}{17}\left(\frac{6}{6}\right)=\frac{54}{102}$ vention had clear and substantial effects on the students' arithmetic performance. Others (e.g., Albion \& Salzberg, 1982; Leon \& Pepe, 1983; Cameron \& Robinson, 1980; Thackwray, Meyers, Schleser, \& Cohen, 1985) also have used self-instructional principles when teaching pupils algorithms for solving arithmetic problems.

An important feature of some of these studies (e.g., Johnston \& Whitman, 1987) is that they have evaluated the teaching of algorithmic knowledge within the context of other instructional components as well. The results of these studies indicate that, although teaching students an algorithm or a strategy is terribly important in their mastery of a mathematical skill, incorporating other factors (e.g., general self-instruction, self-evaluation of answer accuracy) can be beneficial, too. In general, more complete instruction-instruction that teaches all of the steps that pupils will need to function independently - is more effective than less complete instruction (Lloyd, 1988). 


\section{Instructional Packages and Programs}

Some instructional packages incorporate recommendations about helping pupils to develop strategies for solving mathematics problems. Examples of these are given in Table 4. In addition, teachers should examine basal mathematics programs such as those published by Holt (Holt School Mathematics), Scott, Foresman (Mathematics Around Us), Addison-Wesley (Elementary School Mathematics), and Laidlaw (The Understanding Mathematics Program) to determine the extent to which they teach strategic behaviors.

Our previous discussion should help to guide the evaluation of programs for use with atypical learners. We think that instructional programs that are to be used with atypical learners should have several features. They should:

- Include lesson descriptions that permit teachers to adopt and use principles of effective teaching (e.g., frequent student responding on tasks relevant to short- and longterm objectives that are directly related to outcome measures).

- Build mathematical skills in a manner that is consistent with what is known about children's mathematical thinking.

- Teach students explicit algorithms for solving problems, making sure that those algorithms are integrated with related algorithms and that students are taught to use them flexibly.

- Demonstrate their effectiveness by submitting to rigorous field testing and evaluation.

TABLE 4

\section{Selected Commercially Available Arithmetic Programs That Teach Strategies}

\section{Program Name}

Corrective Mathematics Program

Structural Arithmetic

Project Math

DISTAR Arithmetic

Mastering Fractions

Mastering Ratios and Equations
Teachers who select instructional packages would be well advised to examine the available research about packages such as Project MATH (see Cawley, Fitzmaurice, Shaw, Kahn, \& Bates, 1978), DISTAR Arithmetic (see Becker \& Carnine, 1981), and Mastering Fractions (see Hasselbring, Sherwood, \& Bransford, 1986; Kelly, Carnine, Gersten, \& Grossen, 1986).

\section{REFERENCES}

Albion, F.M., \& Salzberg, C.L. (1982). The effect of self-instructions on the rate of correct addition problems with mentally retarded children. Education \& Treatment of Children, 5, 121-131.

Ashcraft, M.H. (1982). The development of mental arithmetic: A chronometric approach. Developmental Review, 2, 213-236.

Becker, W.C. (1986). Applied psychology for teachers: A behavioral cognitive approach. Chicago: Science Research Associates.

Becker, W.C., \& Carnine, D.W. (1981). Direct instruction: A behavior theory model for comprehensive educational intervention with the disadvantaged. In S.W. Bijou \& R. Ruiz (Eds.), Behavior modification: Contributions to education (pp. 145-210). Hillsdale, NJ: Erlbaum.

Brophy, J., \& Good, T.L. (1986). Teacher behavior and student achievement. In M.C. Wittrock (Ed.), Handbook of research on teaching (3rd ed., pp. 328-375). New York: Macmillan.

Brown, J.S., \& Burton, R.B. (1978). Diagnostic models for procedural bugs in basic mathematical skills. Cognitive Science, 2, 155-192.

Cameron, M.I., \& Robinson, V.M.J. (1980). Effects of cognitive training on academic and on-task behavior of hyperactive children. Journal of Abnormal Child Psychology, 8, 405-419.

Carnine, D.W. (1980). Preteaching versus concurrent teaching of the component skills of a multiplication problem-solving strategy. Journal for Research in Mathematics Education, 11, 375-379.

Carpenter, T.R., \& Moser, J.M. (1983). The acquisition of addition and subtraction concepts. In R. Lesh \& M. Landau (Eds.), Acquisition of mathematics concepts and processes (pp. 7-44). New York: Academic Press.

Carpenter, T.R., \& Moser, J.M. (1984). The acquisition of addition and subtraction concepts in grades one through three. Journal for Research in Mathematics Education, 15, 179-202.

Cawley, J.F., Fitzmaurice, A.M., Shaw, R., Kahn, H., \& Bates, H., III (1978). Mathematics and learning disabled youth: The upper grade levels. Learning Disability Quarterly, 1(4), 37-52.

Cox, L.S. (1975). Diagnosing and remediating systematic errors in addition and subtraction computations. Arithmetic Teacher, 22, 151-157.

Cullinan, D., Lloyd, J., \& Epstein, M.H. (1981). Strategy training: A structured approach to arithmetic instruction. Exceptional Education Quarterly, 2(1), 41-49.

Davis, R.W., \& Hajicek, J.O. (1985). Effects of self-instructional training on a mathematics task with severely behaviorally disordered students. Behavioral Disorders, 10, 275-282.

Ebmeier, H., \& Good, T.L. (1979). The effects of instructing teachers about good teaching on the mathematics achievement of fourth grade students. American Educational Research Journal, 16, 1-16.

Engelmann, S., \& Carnine, D. (1982). Theory of instruction: Principles and applications. New York: Irvington.

Fink, W.T., \& Carnine, D.W. (1975). Control of arithmetic errors using informational feedback and graphing. Journal of Applied Behavior Analysis, 8, 461. (Abstract)

Fuson, K.C. (1982). An analysis of the counting-on solution procedure in addition. In T.P. Carpenter, J.M. Moser, \& T.A. Romberg (Eds.), Addition and subtraction: A cognitive perspective (pp. 67-81). Hillsdale, NJ: Erlbaum. 
Geary, D.C., Widaman, K.F., Little, T.D., \& Cormier, P. (1987). Cognitive addition: Comparison of learning disabled and academically normal elementary school children. Cognitive Development, 2, 249-269.

Ginsburg, H.P. (1977). Children's arithmetic: The learning process. New York: D. Van Nostrand.

Good, T.L., \& Grouws, D.A. (1979). The Missouri Mathematics Effectiveness Project: An experimental study in fourth-grade classrooms. Journal of Educational Psychology, 71, 355-362.

Good, T.L., Grouws, D.A., \& Ebmeier, M. (1983). Active mathematics instruction. New York: Longman.

Grimm, J.A., Bijou, S.W., \& Parsons, J.A. (1973). A problem-solving model for teaching remedial arithmetic to handicapped young children. Journal of Abnormal Child Psychology, 1, 26-39.

Groen, G.J., \& Parkman, J.M. (1972). A chronometric analysis of simple addition. Psychological Review, 79, 329-343.

Groen, G.J., \& Resnick, L.B. (1977). Can preschool children invent algorithms? Journal of Educational Psychology, 69, 645-652.

Hasazi, J.E., \& Hasazi, S.E. (1972). Effects of teacher attention on digit-reversal behavior in an elementary school child. Journal of Applied Behavior Analysis, 5, 157-162.

Hasselbring, T., Sherwood, R., \& Bransford, J. (1986). Evaluation of the mastering fractions level one instructional videodisc program. Unpublished manuscript, Tennessee Valley Authority.

Haupt, E.J., Van Kirk, M.J., \& Terraciano, T. (1975). An inexpensive fading procedure to decrease errors and increase retention of number facts. In E. Ramp \& G. Semb (Eds.), Behavior analysis: Areas of research and application. Englewood Cliffs, NJ: Prentice-Hall.

Houlihan, D.M., \& Ginsburg, H.P. (1981). The addition methods of firstand second-grade children. Journal for Research in Mathematics Education, 12, 95-106.

Johnston, M.B., \& Whitman, T. (1987). Enhancing math computation through variations in training format and instructional content. Cognitive Therapy \& Research, 11, 381-397.

Johnston, M.B., Whitman, T.L., \& Johnson, M. (1981). Teaching addition and subtraction to mentally retarded children: A self-instructional program. Applied Research in Mental Retardation, 1, 141-160.

Kelly, B., Camine, D., Gersten, R., \& Grossen, B. (1986). The effectiveness of videodisc instruction in teaching fractions to learning-disabled and remedial high school students. Journal of Special Education Technology, 8(2), 5-17.

Lankford, F.G., Jr. (1972). Some computational strategies of seventh grade pupils (Final Report of Project No. 2-C-013, U.S. Department of Health, Education, and Welfare Grant No. OEG-3-72-0035). Charlottesville, VA: University of Virginia Center for Advanced Studies.

Leon, J.A., \& Pepe, H.J. (1983). Self-instructional training: Cognitive-behavior modification for remediating arithmetic deficits. Exceptional Children, 50, 54-60.

Lloyd, J. (1980). Academic instruction and cognitive-behavior modification: The need for attack strategy training. Exceptional Education Quar. terly, $I(1), 53-63$.

Lloyd, J.W. (1988). Direct academic interventions in learning disabilities. In M.C. Wang, H.J. Walberg, \& M.C. Reynolds (Eds.), Handbook of special education: Research and practice (Vol. 2, pp. 345-366). Oxford, England: Pergamon.

Lloyd, J.W. \& de Bettencourt, L.J. (1982). Academic strategy training: A manual for teachers. Charlottesville, VA: University of Virginia Learning Disabilities Research Institute.

Lloyd, J., Saltzman, N.J., \& Kauffman, J.M. (1981). Predictable generalization in academic learning as a result of preskills and strategy training. Learning Disability Quarterly, 4, 203-216.

Lovitt, T.C., \& Curtiss, K.A. (1968). Effects of manipulating an antecedent event on mathematics response rate. Journal of Applied Behavior Analysis, 1, 329-333.

Montague, M., \& Bos, C.S. (1986). The effect of cognitive strategy training on verbal math problem solving performance of learning dis- abled adolescents. Journal of Learning Disabilities, 19, 26-33.

Paine, S.C., Carnine, D.W., White, W.A.T., \& Walters, G. (1982). Effects of fading teacher presentation structure (covertization) on acquisition and maintenance of arithmetic skills. Education \& Treatment of Children, 5, 93-107.

Parsons, J.A. (1972). The reciprocal modification of arithmetic behavior and program development. In G. Semb (Ed.), Behavior analysis and education-1972 (pp. 185-199). Lawrence: University of Kansas, Department of Human Development.

Pellegrino, J.W., \& Goldman, S.R. (1987). Information processing and elementary mathematics. Journal of Learning Disabilities, 20, 23-32, 57.

Resnick, L.B. (1983). A developmental theory of number understanding. In H.P. Ginsburg (Ed.), The development of mathematical thinking (pp. 109-151). New York: Academic Press.

Rivera, D., \& Smith, D.D. (1988). Using a demonstration strategy to teach midschool students with learning disabilities how to compute long division. Journal of Learning Disabilities, 21, 77-81.

Romberg, T.A., \& Carpenter, T.P. (1986). Research on teaching and learning mathematics: Two disciplines of scientific inquiry. In M.C. Wittrock (Ed.), Handbook of research on teaching (3rd ed., pp. 850873). New York: Macmillan.

Rosenshine, B. (1976). Classroom instruction. In N.L. Gage (Ed.), The psychology of teaching methods (77th yearbook of the National Society for the Study of Education). Chicago: University of Chicago Press.

Rosenshine, B., \& Stevens, R. (1986). Teaching functions. In M.C. Wittrock (Ed.), Handbook of research on teaching (3rd ed., pp. 376-391). New York: Macmillan.

Russell, R.L. (1977). Addition strategies of third grade children. Journal of Children's Mathematical Behavior, 1(4), 149-160.

Schunk, D.H. (1981). Modeling and attributional effects on children's achievement: A self-efficacy analysis. Journal of Educational Psychology, 73, 93-105.

Schunk, D.H., \& Cox, P.D. (1986). Strategy training and attributional feedback with learning disabled students. Journal of Educational Psychology, 78, 201-209.

Secada, W.G., Fuson, K.C., \& Hall, J.W. (1983). The transition from counting-all to counting-on in addition. Journal for Research in Mathematics Education, 14(1), 47-57.

Siegler, R.S., \& Robinson, M. (1982). The development of numerical understandings. In H.W. Reese \& C.P. Lipsitt (Eds.), Advances in child development and behavior (Vol. 16, pp. 241-312). New York: Academic Press.

Smith, D.D., \& Lovitt, T.C. (1975). The use of modeling techniques to influence the acquisition of computational arithmetic skills in learningdisabled children. In E. Ramp \& G. Semb (Eds.), Behavior analysis: Areas of research and application (pp. 283-308). Englewood Cliffs, NJ: Prentice-Hall.

Smith, D.D., \& Lovitt, T.C. (1976). The differential effects of reinforcement contingencies on arithmetic performance. Journal of Learning Disabilities, 9, 21-29.

Smith, D.D., Lovitt, T.C., \& Kidder, J.D. (1972). Using reinforcement contingencies and teaching aids to alter subtraction performance of children with learning disabilities. In G. Semb (Ed.), Behavior analysis and education-1972 (pp. 342-360). Lawrence: University of Kansas, Department of Human Development.

Svenson, O., \& Broquist, S. (1975). Strategies for solving simple addition problems. Scandinavian Journal of Psychology, 16, 143-151.

Thackwray, D., Meyers, A., Schleser, R., \& Cohen, R. (1985). Achieving generalization with general versus specific self-instructions: Effects of academically deficient children. Cognitive Therapy \& Research, 9, 291-308.

Whitman, T., \& Johnston, M.B. (1983). Teaching addition and subtraction with regrouping to educable mentally retarded children: A group self-instructional training program. Behavior Therapy, 14, 127-143.

Young, R.M., \& O'Shea, T. (1981). Errors in children's subtraction. Cognitive Science, 5, 153-177. 


\section{Xxcellence in Educating he Gifted}

ohn F. Feldhusen, Purdue University

oyce L. Van'Tassel-Baska, College of William

nd Mary

Cen R. Seeley, Clayton College (Denver)

\section{HOMTHID PRDDACDO}

he highest satisfaction in life comes to those who use their bilities and talents to the fullest extent and who create new leas, inventions or works of art. Thus, this book was conived to delineate the many facets of gifted individuals nd their learning patterns, so that they may be enabled to ach their greatest potential.

n expansion of an earlier, well-respected text, this book mains in the vanguard of gifted education. It offers a omprehensive introduction to the key topics, issues, and

\section{POCWATHDAURES}

Points out major study results - Terman and Oden, the Marland Report, Leadership Training Institutes

Discusses issues and controversies, including the "pull-out" resource room model

Addresses concerns about enrichment, acceleration, individualization

Emphasizes the roles of facilitators - teachers, counselors, mentors

\section{(DNHDIST)}

1 Introduction

art I The Gifted and Individual Differences

2 Characteristics and Needs of the Gifted

3 Underachieving and Handicapped Gifted Learners

4 Gifted Girls

5 Disadvantaged Gifted Learners

6 The Highly Gifted

7 Identification and Assessment of the Gifted

art II Program Development

8 Program Models for Gifted Education

9 A Comprehensive Model of Gifted Program Development

0 Evaluating Programs for Gifted Learners

1 Key Administrative Concepts in Gifted Program

Development

controversies in the field. Major topical areas include: the nature of giftedness; specific gifted subpopulations; identification processes; program development; curriculum and instruction, and facilitators (teachers, counselors, mentors).

Contributors to the book are experts in the field, offering insights from both research and experiential backgrounds. Specific methods and strategies, based on strongly developed philosophical underpinnings, give practical teaching suggestions to help the beginning and experienced educator.

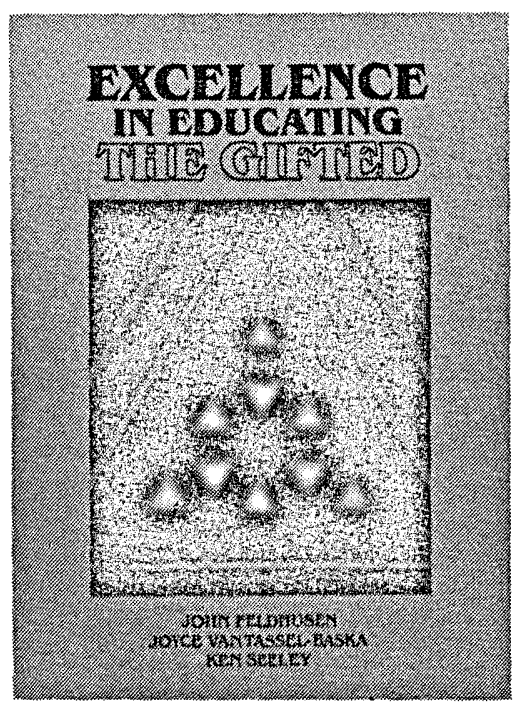

\section{Part III Curriculum and Instruction}

12 Appropriate Curriculum for the Gifted

13 Math and Science Curriculum for the Gifted

14 Social Studies and Language Arts for the Gifted

15 Arts and Humanities for the Gifted

16 Thinking Skills for the Gifted

17 Instructional Methods for the Gifted

Part IV Helping the Gifted Achieve Excellence

18 Facilitators for Gifted Learners

19 Counseling the Gifted

20 Synthesis

8901/hardbound/ISBN 0-89108-205-0 


\section{Professional update}

\section{Number and Percent of all Handicapped Children and Youth \\ Served in Nine Educational Environments by Age Group \\ During School Year 1985-86}

Environment

3-5 Years

6-11 Years

12-17 Years

18-21 Years

Number Percent Number Percent Number Percent Number Percent

\begin{tabular}{|c|c|c|c|c|c|c|c|c|}
\hline Regular Class & 109,431 & 36.89 & 726,586 & 35.88 & 277,424 & 15.60 & 21,908 & 9.66 \\
\hline Resource Room & 58,718 & 19.79 & 807,144 & 39.86 & 849,989 & 47.81 & 75,429 & 33.25 \\
\hline Separate Class & 78,487 & 26.46 & 408,345 & 20.16 & 500,315 & 28.14 & 72,601 & 32.01 \\
\hline $\begin{array}{l}\text { Public Separate } \\
\text { School Facility }\end{array}$ & 22,797 & 7.68 & 40,955 & 2.02 & 71,870 & 4.04 & 28,451 & 12.54 \\
\hline $\begin{array}{l}\text { Private Separate } \\
\text { School Facility }\end{array}$ & 18,577 & 6.26 & 22,199 & 1.10 & 23,784 & 1.34 & 6,507 & 2.87 \\
\hline $\begin{array}{l}\text { Public Residential } \\
\text { Facility }\end{array}$ & 3,659 & 1.23 & 9,532 & 0.47 & 18,018 & 1.01 & 10,673 & 4.71 \\
\hline $\begin{array}{l}\text { Private Residential } \\
\text { Facility }\end{array}$ & 330 & 0.11 & 3,420 & 0.17 & 9,567 & 0.54 & 2,487 & 1.10 \\
\hline Correction Facility & 38 & 0.01 & 197 & 0.01 & 7,948 & 0.45 & 5,073 & 2.24 \\
\hline Homebound/Hospital & 14,614 & 1.56 & $6 ; 813$ & 0.34 & 18,952 & 1.07 & 3,709 & 1.64 \\
\hline
\end{tabular}

Data as of October $1,1987$.

From Tenth Annual Report to Congress on the Implementation of the Education of the Handicapped Act, 1988, Washington, DC:

U.S. Department of Education, p. 32. 